\title{
FRAUDES, PLÁGIOS E CURRÍCULOS
}

Volta e meia surgem-nos fatos que colocam estruturas consolidadas do meio acadêmico em situação constrangedora. Estamos nos referindo aos recentes ataques de pessoas inescrupulosas contra a Plataforma de Currículos Lattes do CNPq. Quando essas ações nefastas aparecem, surgem os oportunistas de plantão com o discurso que o sistema é falho e deveria ser mais controlado. A ideia de controle aos serviços de acesso aberto às informações (open access), praticada pela Plataforma Lattes e por muitas revistas científicas como, por exemplo, as revistas da Sociedade Brasileira de Química, está em oposição à cultura e aos caminhos da internet.

Em diversas oportunidades já discutimos esse assunto. Porém, nunca é demais relembrá-lo e mostrar como os gestores dos serviços de acesso aberto estão lidando com esta situação.

É inquestionável o avanço e a transparência que a Plataforma Lattes trouxe para a comunidade científica quando foi introduzida em 1999. Hoje é possível consultar o currículo de qualquer pesquisador em qualquer lugar do país e tomar conhecimento da sua produção acadêmica mais recente. As empresas também têm se servido da Plataforma para busca de profissionais e consultores. Um aspecto importante foi a praticidade que ela trouxe aos pesquisadores que antes tinham que fazer diversos modelos de currículo dependendo da agência financiadora. Com isso, as agências que financiam a pesquisa e as concessões de bolsas ficam mais seguras das decisões tomadas e os proponentes podem fazer suas próprias avaliações. É bom lembrar que o currículo nem sempre é o fator decisivo na aprovação de um projeto. Contudo, toda essa abertura tem um preço, a nosso ver mínimo, que são as fraudes e os plágios. Algumas de tão grotescas são de fácil percepção, porém outras necessitam de análise mais acurada.

De forma similar as revistas científicas de acesso aberto, ou não, também são objetos de fraudes e plágios. Muitas destas já foram amplamente divulgadas em diversas publicações e foram tema de editoriais da Química Nova ${ }^{1,2}$ e do Journal of the Brazilian Chemical Society. ${ }^{3}$

Felizmente, esses casos são em percentuais baixíssimos, mas que devem ser constantemente combatidos e amplamente divulgados. O mais interessante é a impressão de que os casos de fraudes e plágios aumentaram significativamente, mas devemos lembrar que o número de artigos publicados também cresceu bastante com o advento das novas publicações eletrônicas e que, consequentemente, as publicações ficaram mais visíveis, podendo ser detectados mais facilmente.

As fraudes nas publicações científicas podem ocorrer de diversas maneiras: na autoria com exclusão de autores ou inclusão de autores que não tiveram participação no trabalho, apropriação de dados de outros, ausência intencional de citação de fontes ou referências, ocultação ou fabricação de dados de um experimento, tratamento de dados intencionalmente feito de forma a provar algum aspecto que interessa os autores etc. Algumas fraudes são denunciadas por autores prejudicados. Porém, as duas últimas fraudes mencionadas levam mais tempo para serem detectadas, pois muitas vezes envolvem pequenas incorreções em experimentos que somente serão comprovadas com a repetição dos mesmos por outros grupos de pesquisa. Mesmo assim, em alguns casos ainda podem ficar dúvidas se o experimento foi, ou não, conduzido da mesma forma. Erros podem ocorrer na interpretação de dados, e isso é normal para aqueles que se aventuram na busca do conhecimento inédito. Por exemplo, existem diversos relatos de estruturas de produtos naturais que foram equivocadamente publicadas e depois revisadas. Existem casos em que não houve uma má intenção do autor no relato do experimento, mas alguma condição reacional interferiu no curso da reação levando a um resultado não esperado. De qualquer forma, sempre há espaço nas revistas para uma revisão do resultado pelos próprios autores e isso tem sido praticado. Em resumo, fraude nas publicações científicas representa a desonestidade frente aos seus pares, onde o fraudador tenta levar vantagem sobre seus colegas, além do dano que pode causar dependendo da área científica em que esteja atuando.

De forma similar os currículos apresentam fraudes como cursos de formação que nunca foram feitos ou complementados, participações em congressos colocadas como publicações e, a mais grave, usurpação de publicações alheias.

O plágio é mais sutil e também extremamente danoso. Não são apenas as publicações científicas que sofrem com plágio. A música, literatura e a arte são também alvos da apropriação das ideias e textos, às vezes de forma sutil e parcial. $\mathrm{O}$ plágio mais comum é o autoplágio, onde o autor repete parte dos seus dados ou texto, muitas das vezes apenas nas introduções. Entretanto, o caso mais nefasto de plágio é a repetição da publicação com os mesmos dados em revistas diferentes, às vezes no mesmo ano.

Entre os autores e a comunidade científica estão os editores e os assessores $a d$ hoc. Os editores são membros respeitáveis dessa comunidade que acabam sendo responsáveis pelos artigos publicados e de certa forma conferindo credibilidade. Porém, esta responsabilidade deve ser dividida com toda a comunidade, pois os editores se baseiam nos pareceres dos revisores, que deveriam analisar os artigos com mais profundidade. Porém, cada vez mais artigos são enviados para os revisores pelas revistas, tornando quase impossível uma investigação profunda de fraude ou plágio pelo autor.

Recentemente, a Plataforma Lattes incluiu o DOI das publicações e o cruzamento com o banco de teses da CAPES procurando dar mais confiabilidade às informações disponíveis. Da mesma forma as revistas e editoras tem tentado desenvolver sistemas e mecanismos eficientes para conduzir buscas na literatura científica, permitindo aos editores de revistas que identifiquem a ocorrência de plágios nos textos (eTBLAST, Dejà vu etc.). Porém, até o momento não existe um método infalível de detecção de plágios. Também existem algumas páginas da internet dedicadas a denunciar casos de plágios nas publicações científicas.

Dentro deste debate existem outras questões. Porém, a mais importante é o que fazer quando uma revista detecta as fraudes e os plágios. A situação mais comum é a eliminação do artigo das bases de dados eletrônicas e a divulgação para o meio acadêmico, e isso tem sido feito por diversas revistas, inclusive a Química Nova. Porém, o que foi publicado na forma impressa não há como ser recolhido e pode até continuar sendo citado por pesquisadores que fazem a citação sem ter acessado o artigo original (citação de citação).

A fraude na Ciência não é novidade. Ela sempre existiu e é anterior às publicações em periódicos e, atualmente, é impulsionada pelo interesse em publicar mais artigos e obter mais recursos para a pesquisa e, assim, ascender na carreira científica, na busca de melhores salários e ter um belíssimo currículo Lattes. Portanto, é muito bom refletir, quando esses casos são descobertos, se as revistas científicas devem ser as únicas responsabilizadas pela insanidade e a ganância de certos pesquisadores.

Susana I. Córdoba de Torresi
Vera L. Pardini
Vitor F. Ferreira
Editores de QN

\section{REFERÊNCIAS}

1. Coelho, F. S.; Editorial, Quim. Nova 2006, 29, 185.

2. Torresi, S. I. C.; Pardini, V. L.; Ferreira, V. F.; Quim. Nova 2008, 31, 197.

3. Pinto, A. C.; Editorial, J. Braz. Chem. Soc. 1999, 10, nº 2. 